\title{
Salinization Threats to Agriculture across the North Sea Region
}

lain Gould, Jeroen De Waegemaeker, Domna

Tzemi, Isobel Wright, Simon Pearson, Eric

Ruto, Leena Karrasch, Laurids Siig Christensen,

Henrik Aronsson, Susanne Eich-Greatorex,

Gary Bosworth, and Pier Vellinga

\section{CONTENTS}

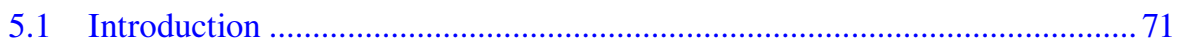

5.2 Causes of Salinization in the North Sea Region............................................ 74

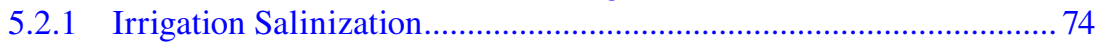

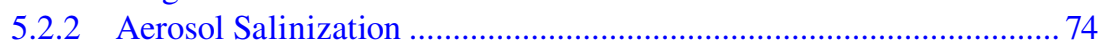

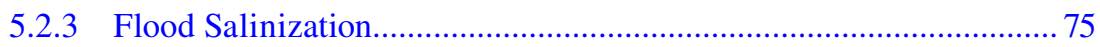

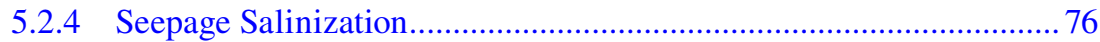

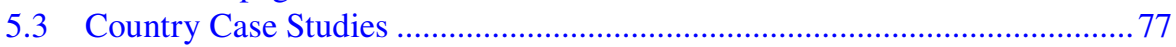

5.3.1 United Kingdom .............................................................................

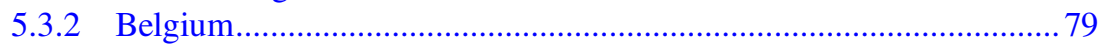

5.3.3 The Netherlands............................................................................

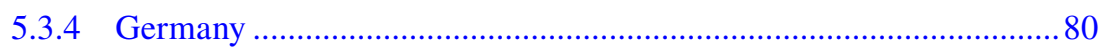

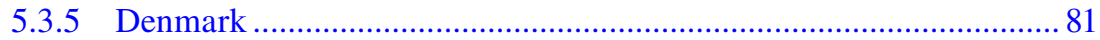

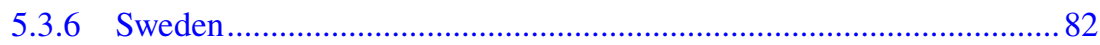

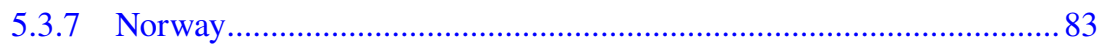

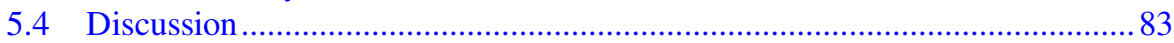

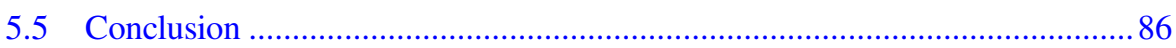

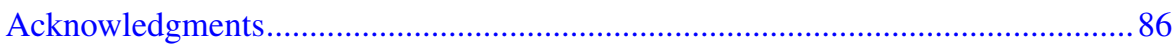

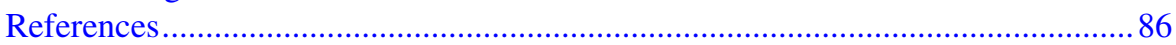

\subsection{INTRODUCTION}

Agricultural production faces unprecedented challenges in the 21st century (Foley et al. 2011). By the end of the century, the global population may reach upwards of 11 billion (UN 2017), with evolving dietary requirements adding further pressures on land resources (Bodirsky et al. 2015). All of this will evolve against a backdrop of a changing climate that could have severe implications for yields and production 
(Agovino et al. 2019). The sustainable management of agricultural land, and soils, will be key to addressing this challenge. Soils produce around $95 \%$ of our food, and if managed well, even have some capacity to mitigate the harmful effects of flooding and drought, whilst also sequestering carbon (FAO 2015). Nevertheless, global soil health is under threat, with around a third of the world's soils already suffering from degradation (FAO 2015); in many parts of the world, a major driver of this degradation is salinization (Rengasamy 2006; Qadir et al. 2014; FAO 2015).

High levels of salts in soil have direct effects on crop yields by impacting osmotic potential thus reducing plant water uptake (Abrol et al. 1988), but also have severe consequences for longer-term soil function and agricultural production (Pitman and Läuchli 2002). Sodium ions $\left(\mathrm{Na}^{+}\right)$bind to the exchange sites on clay particles, increasing the chance of clay dispersal (Abrol et al. 1988). Once dispersed, soils are susceptible to structural degradation, resulting in surface slaking and reduced infiltration rates (Paes et al. 2014). Soil dispersal can also expose previously-occluded soil organic matter to decomposition, altering the microbial structure and carbon cycling of a soil (Rath and Rousk 2015). Salts can accumulate at the soil surface and root zone following evaporation of soil water, whereas an increased flushing with fresh water can aid salt removal.

It is estimated that salt affected soils cover 932.2 Mha globally, with Europe contributing about 30.7 Mha or $3.3 \%$ of total global saline and sodic soils (Rengasamy 2006). Well documented regions of concern range from central Asia, North and South America, Australia, the Middle East and parts of Africa and Southern Europe. These constitute mainly arid and semi-arid regions where salinization is intensified by high temperatures and rapid evaporation, surface water resources are scarce, and irrigation utilizing water sources of high ionic strength is widely practiced (Endo et al. 2011; Cui et al. 2019).

Salinity is not solely confined to arid and semi-arid regions and can still manifest as a threat to soils in areas of higher rainfall with greater flushing rates, most notably in coastal zones (Tóth et al. 2008; Jones et al. 2012; Daliakopoulos et al. 2016). Under future climate predictions, one area at particular risk of salinization is the North Sea region (Figure 5.1), with its combination of low-lying land, productive farming in coastal regions and reliance on a regulated water supply to maintain crop requirements. Throughout the North Sea region, localized pockets of land have been subjected to salinization processes, such as from seawater inundation (Gerritsen 2005; Wadey et al. 2015), however, the occurrence of salinization in the region is sporadic. The risk to agricultural soils inherently differs as a result of varying climatic and geological conditions and management factors such as flood defence, land drainage and extent of irrigation (Daliakopoulos et al. 2016). Existing frameworks summarize the salinization process on a global and wider European scale (Tóth et al. 2008; Daliakopoulos et al. 2016). These are comprehensive but not specific to the northern coastal regions surrounding the North Sea, a maritime region where the multiple salinization threats are a function of marine and coastal dynamics. Furthermore, in coastal regions, multiple processes often occur within the same locality. As a result, novel frameworks need to be employed to summarize the salinization risks solely in the North Sea region. 


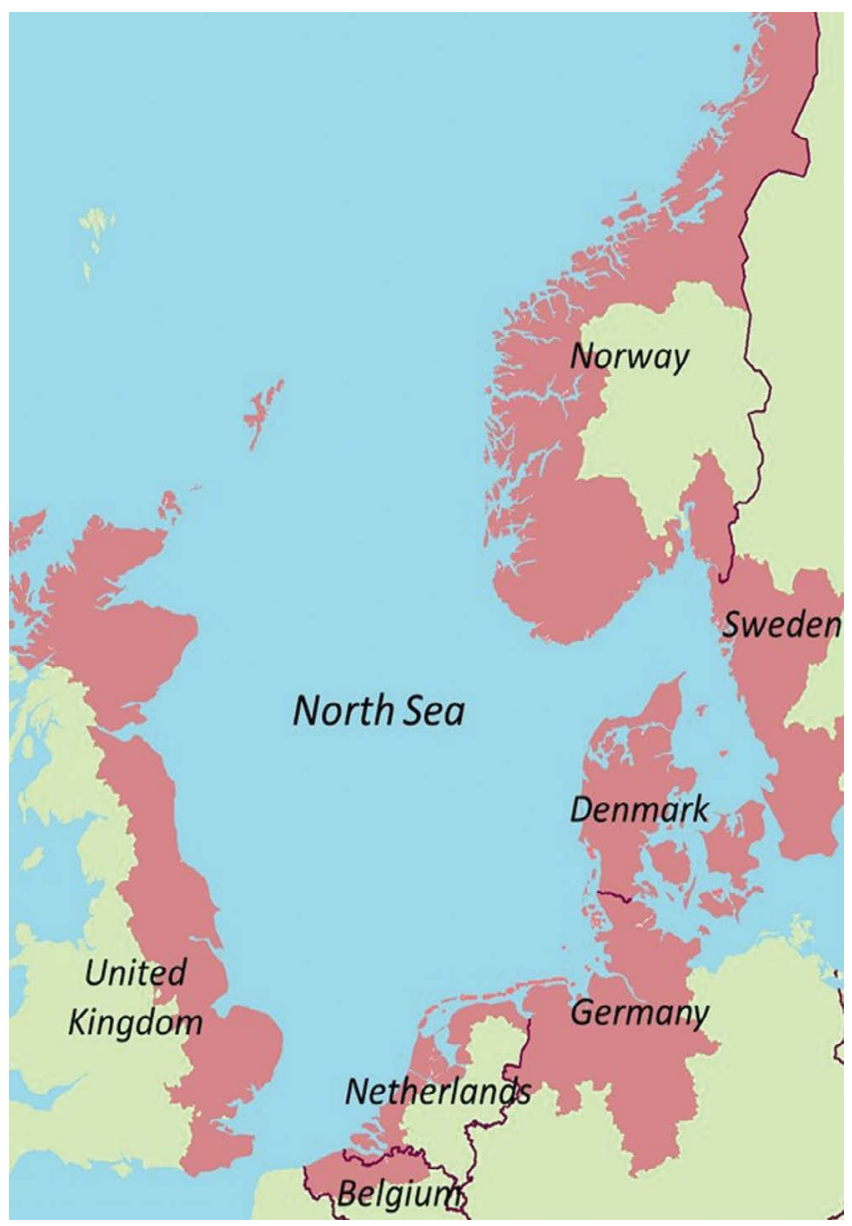

FIGURE 5.1 The North Sea region.

Given future climatic predictions, we anticipate greater threat of salinity to agricultural systems around the North Sea. Salinization will impact on agricultural systems in the region through a range of mechanisms from flooding, saline intrusion of groundwater, irrigation with brackish water or airborne salinity (De Waegemaeker 2019). Agricultural land managers will need to explore ways to adapt, but at present, very little research exists that investigates the issue of salinity in North Sea coastal region agriculture.

In this chapter, we provide an overview of salinity occurrence in the North Sea countries with the aim of identifying knowledge gaps for developing a strategy for agricultural salinity adaptation in the region. On account of limited existence of quantitative, comparable, salinity data across the region, this review presents an exploration of salinization in the region, rather than a comprehensive review of every country. 


\subsection{CAUSES OF SALINIZATION IN THE NORTH SEA REGION}

We first propose a suitable framework to categorize the common mechanisms of land salinization shared by all of the North Sea coastal regions. In a 2019 report for the Interreg VB North Sea Region SalFar project (“Saline Farming”), De Waegemaeker (2019) developed a framework of four key pathways, which would cause salinization of agricultural land across the North Sea region. This framework simplifies previous work by Manca et al. (2015) and Daliakopoulos et al. (2016) that elaborate on salinization issues across multiple climate zones. This review builds on the original De Waegemaeker (2019) framework and in doing so, we discuss the four salinization pathways: (1) irrigation, (2) aerosol, (3) flood and (4) seepage salinization; and how they may evolve in a changing climate (Figure 5.2.).

\subsubsection{IrRigation Salinization}

Salinization by irrigation is a widespread and well documented problem across many arid and semi-arid parts of the globe (Rengasamy 2006). In such climates, the strong evaporative forces leave salt residue from irrigation water at the soil surface, leading to soil salinization. In many instances, the source of irrigation water is from groundwater reserves, which have a higher ionic strength than surface waters. In the maritime climate of the North Sea region, we expect more of a dominance of salt flushing from natural rainfall as confirmed by a study of the dynamics of soil salinization in Denmark (Christensen 2021). Unlike arid regions, irrigation salinization in the North Sea region will likely only manifest in instances where an originally freshwater resource has become salinized to some extent, or where growers utilize more brackish sources in instances where freshwater is becoming scarce. Climate models predict warmer and drier summers, and milder and rainier winters in Northern Europe (Palmer and Räisänen 2002; Rowell and Jones 2006). With growing variability in rainfall events (Pendergrass et al. 2017), farmers may resort to further reliance on irrigation systems. As the requirements of agriculture, households and industry compete for an ever more limited water resource, the utilization of brackish water reserves, if deemed viable, may be an option for growers.

\subsubsection{Aerosol Salinization}

Coastal farmland is also at risk of airborne salinization (Rozema et al. 1983; McCune 1991). Key factors affecting the process are meteorological - namely the speed and direction of the wind (Franzén 1990). Wind speed needs to exceed 4 metres per second in order for the wind to take up droplets of seawater (O'Dowd and de Leeuw 2007). As such, aerosol salinization in the North Sea region may be more common in areas exposed to higher winds, for example prevailing winds, and less so in sheltered areas (Franzén 1990). The North Sea region is generally subject to westerly winds, and thus we may anticipate more aerosol salinization at the eastern end of the Sea. The majority of airborne salts are deposited within $1 \mathrm{~km}$ of the coast (Gustafsson and Franzén 1996). Topographic obstacles to airborne transmission, such as a dune belt, could offer protection of the hinterlands from aerosol salinization. Nevertheless, 


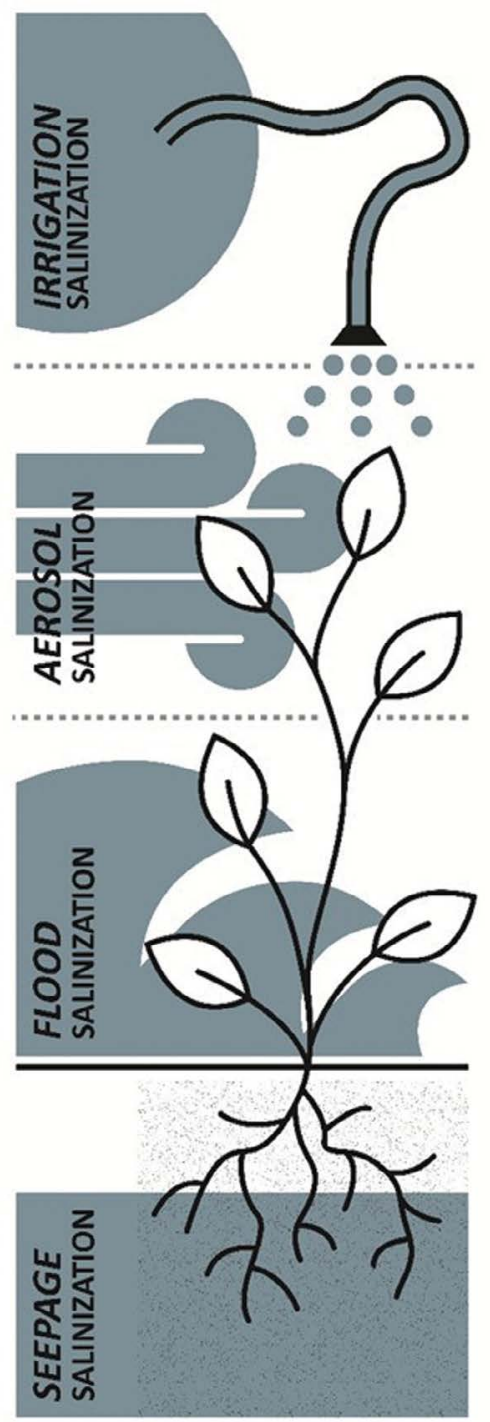

FIGURE 5.2 Four salinization processes of the North Sea region. (De Waegemaeker 2019).

aerosol deposition of salts has been known to travel much further inland (Balance and Duncan 1985). In a changing climate, the degree of aerosol salinity will be determined by how wind patterns may manifest.

\subsubsection{Flood Salinization}

Projections from the IPCC point to a worst-case scenario of sea level rise of between 61 and $110 \mathrm{~cm}$ by 2100 (IPCC 2019). Such a rise, alongside a predicted increase in 
storm surge frequency, will put coastal areas at risk of widespread coastal flooding and the inundation of agricultural soils with saltwater (Nicholls and Cazenave 2010; Brecht et al. 2012; Salehin et al. 2018). The North Sea region will be no exception, and in fact, may be particularly exposed to this rise in sea level (Vousdoukas et al. 2017); the incidence of coastal flooding is therefore forecast to rise in the region (European Environment Agency 2019). Furthermore, changing weather patterns could lead to more unpredictability in storm surge events (Woth et al. 2006), of the scale that has severely damaged North Sea agriculture in the past (Steers et al. 1979).

The severity of flood salinization will not only depend on environmental factors, such as the salinity of the water source, the duration and the extent of the flood, alongside the land's capacity to recover, but also on post-flood management factors such as the availability of machinery, cultivation and crop choice. Around the coasts of the Netherlands, Belgium and the UK, the North Sea has a typical salt content of $3.5 \%$ (Raats 2015), whilst closer to the Baltic, and in estuarine areas, the salinity levels are reduced by dilution with freshwaters. In terms of flood duration, some coastal floods can last only a few hours, whilst others caused by sea defence failures in very low-lying areas can last weeks or months, even resulting in land abandonment (Fagherazzi et al. 2019). Even a short-duration flood event can have devastating impacts on the land (Durant et al. 2018). Finally, the soil type and land management will also determine how persistent salts may remain in the soil, and also the speed of recovery e.g. salt flushing. Clay soils not only have slower infiltration, and thus reduced salt flushing rates, but also can exhibit more structural damage from sodification (Abrol et al. 1988). Taking into account all three of these factors, some areas of the North Sea region may recover quickly, with salinity only being a problem in the short duration following flooding, whilst in other situations, salinity could impact on crop yields for a long time, or even lead to permanent changes in land management (Gould et al. 2020).

\subsubsection{Seepage Salinization}

Salinization by seepage involves the subsurface movement of saline or brackish water to bring it into contact with surface waters, shallow groundwater reserves or the soil root zone via saline intrusion. Saline intrusion can impact on agricultural lands by permeating into freshwater sources, such as surface or groundwater resources utilized for crop production. Additionally, in certain instances, the saline interface could rise up to within crop root zone itself (Stofberg et al. 2017). The rate of intrusion depends on two key factors: (i) the upward encroachment of saline water and (ii) the downward pressure of freshwater (de Louw et al. 2011). If more upward pressure is exerted from beneath, as a result of rising sea levels, storm surge events or sea level rise (Masterson and Garabedian 2007; Werner et al. 2013), the saline interface is forced upwards. Consequently, if less freshwater pressure is being placed from above, for example from increased freshwater abstraction or reductions in rainfall recharge (European Environment Agency 2019), the saline interface will also rise towards the surface. Michael et al. (2017) recently termed the pressure on coastal aquifers "coastal groundwater squeeze", which threatens coastal groundwater resources by overuse and contamination. In a changing climate, these drivers - from above and 
from below - will bring the issue of seepage salinization to increasing significance in coastal agricultural areas of the North Sea region.

\subsection{COUNTRY CASE STUDIES}

\subsubsection{UnITED KINGDOM}

Many coastal areas of Eastern England have a long history of reclamation, drainage and conversion to productive arable land (Hazelden and Boorman 2001). As a result, much of the UK's most productive agricultural land is found in these low-lying areas of fertile soils, areas also occupying flood risk zones, with water levels managed by Internal Drainage Boards. North Sea storm surges flooded east coast farmland in events in 1953, 1978 and 2013 (Steers et al. 1979; Baxter 2005; Spencer et al. 2015). Farms most at risk to these saline inundations can be areas of particularly high value: growing potentially less salt tolerant crops, such as salads and potatoes, exposing vulnerabilities to regional agricultural economies if coastal flood incidence rises (Gould et al. 2020). In many areas along the North Sea coast, there is continual debate over the cost/benefit of maintaining flood defences and of nature-based adaptation (Liski et al. 2019), keeping the risk of flood inundation ever present in the attention of UK coastal farmers.

In addition to flooding, there is concern regarding seawater intrusion into some of the UK's coastal aquifers, such as the chalk aquifers, a valuable freshwater resource (MacAllister et al. 2018). These deep aquifers are not considered a direct pathway to agricultural soil salinity (Cooper et al. 2010), but agricultural abstraction licenses are in place for other groundwater reserves and surface waters in coastal regions to supply irrigation systems (Weatherhead et al. 2014), areas in which seepage salinization could compromise public and private abstraction.

The extent of salt affected soils in the UK is unknown, although considered not to be insignificant (Loveland et al. 1986). Given the aforementioned mechanisms, the potential for salinization is geographically extensive, and not localized to any one agricultural region along the North Sea coastline. As recently as 2013, coastal flooding inundated farmland in areas around the Humber, south Lincolnshire, Norfolk, Suffolk, Essex and Kent (NFU 2013; Wadey et al. 2015) (Figure 5.3a). Eastern coasts of Scotland have been subject to periodic flood events, and coastal defences are in place to protect property and farmland (Hickey 1997). The Norfolk Broads (which have RAMSAR and SAC designations) have been subjected to increased salinity, both from changes to local water management and also as an impact of storm surges (Roberts et al. 2019). Former salt marsh lands of Essex, Kent and other parts of Southern and Eastern England, areas which have undergone past conversion to farmland, can exhibit a degree of salinity, and faced with greater coastal flooding, their longevity as productive farmland may be in question (Hodgkinson and Thorburn 1995; Hazelden and Boorman 2001 ); the financial impacts of a flood on prime agricultural land could cost up to $£ 5,000$ per hectare (Gould et al. 2020). Furthermore, farmland in South Lincolnshire and East Anglia receives less rainfall compared to the rest of the UK (Mayes and Wheeler 2013) and thus has a demand for irrigation (Rey et al. 2016) with less salt flushing potential from natural rainfall. By 2050, 


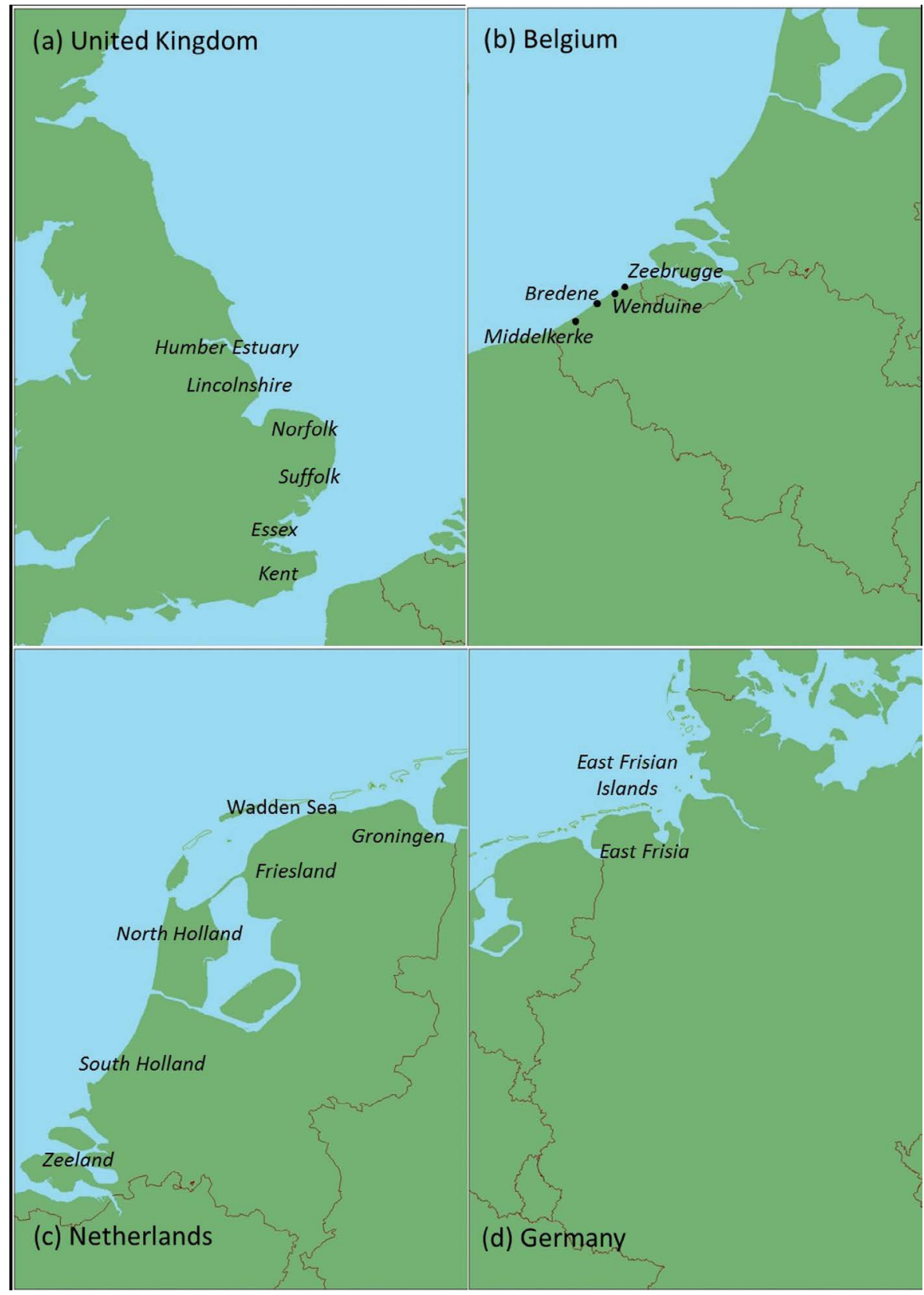

FIGURE 5.3 Locations discussed in the United Kingdom (a); Belgium (b); the Netherlands (c); Germany (d). 
the water requirements of agriculture in these regions will face increased pressure (Environment Agency 2020). Some growers in these areas, faced with limitations in irrigation supply and confronted with brackish surface and groundwater, are starting to explore trials with brackish water irrigation.

\subsubsection{Belgium}

Most of the Belgian coastal plain was reclaimed in the 11th and 12th centuries (Tavernier et al. 1970), and surface water today is maintained by a system of drainage and pumping of surface waters to manage winter and summer levels. The phreatic aquifer at the Belgian coast constitutes a freshwater lens situated on top of saline groundwater (Vandenbohede et al. 2015). The cartography of the freshwater lens showcases the local geology; the lens is thickest at the sandy ridges and thinnest in the lowest-lying areas (Vandenbohede et al. 2010; VMM 2014; Delsmans et al. 2019). In some exceptional cases, mainly grassland, the saline groundwater interface is located at less than 2 metres depth. A comparison of the current situation to research from the 1970s indicates that the freshwater lens at the Belgian coast is relatively stable at present (Vandenbohede et al. 2010). Nonetheless, water managers need to be vigilant as climate change exacerbates seepage salinization.

The closer to the Belgian coast, the more sea level rise puts pressure from below on this freshwater lens (Lebbe et al. 2008). At two sections of the coast, namely between Middelkerke and Bredene, and between Wenduine and Zeebrugge (Figure 5.3b), the dune belt is narrow (50-150 metres wide). Here, the small dune area offers flood protection but it is not sufficient to prevent the seepage of seawater to the adjacent polder area, as the fresh groundwater reserve under this narrow dune belt is shallow (Oude Essink 2001; Lebbe et al. 2008). In addition to this upward encroachment near the North Sea, there is pressure from below on the freshwater lens along the Boudewijn canal, which connects the city of Bruges to the port (VMM 2014). In this case, saline water seeps from the canal to the adjacent polders.

The water availability in Belgium is likely to change with future climate predictions (Tabari et al. 2015) leading to periodic reductions in downward pressure on the freshwater lens. Recently the province of West-Flanders was confronted with prolonged droughts, for example in the summer of 2017, 2018 and 2019 (CIW 2018, 2019, 2020). These extreme weather events foreshadow the impact of climate change on local water management and agriculture. In the aforementioned droughts, all available water was directed to the rivers and canals in order to ensure navigability and, as a result, there was no water left to increase the level of surface waters in the polders. In addition, farmers were prohibited from pumping groundwater for irrigation in order to stall seepage salinization.

\subsubsection{The Netherlands}

Agriculture in the Netherlands has a long and rich history of land reclamation, drainage and water management (Hoeksema 2007), resulting in the characteristic polder landscape we know today. With around a quarter of its land surface below sea level (Huisman et al. 1998), the Netherlands has seen its share of historic coastal floods 
leading to soil salinization (Raats 2015). However, after every flood dikes were raised above the levels of the last flood. In the aftermath of devastating floods in the early to mid 20th century, significant investment was allocated to the construction of a series of dams and flood barriers in the following decades (Raats 2015). As such, much of the coastline is protected by defences based on withstanding a 1 in 4,000 to 1 in 10,000-year event, constituting a much more robust coastal flood defence system than other North Sea countries. In fact, it is estimated that without this extensive defence network, $65 \%$ of the country's land surface would suffer regular flooding (Huisman et al. 1998). As a consequence of this investment, the likelihood of saline inundation of Dutch farmland is much less than in other countries, but it can never be ruled out (Bouwer and Vellinga 2007; Vousdoukas et al. 2016).

The more pressing issue concerning exposure of agricultural systems to salinity in the Netherlands is through the impacts of saline groundwater seepage. The major part of the low-lying coastal area has a history of being flooded with every tide. As a geological relict, the groundwater at around 4 metres or below exhibits a degree of salinity, either brackish or saline. Compared to other North Sea countries, the Netherlands benefits from more extensive research activity exploring salinity and groundwater dynamics (de Louw et al. 2010; Oude Essink et al. 2010; de Louw 2013). Beauchampet (2019) provides a comprehensive review of agriculture and salinization from groundwater in the Netherlands, which we briefly summarize in this case study. In the coastal areas of the Netherlands, model simulations predict up to twofold rise in salt levels as a result of groundwater seepage from sea level rise pressures by 2100 (Oude Essink et al. 2010). The predicted increase in saline seepage will not only come from rising saline interfaces, but also by lowering ground levels due to subsidence (Oude Essink et al. 2010). As a result, the most vulnerable areas to salinization are located in the reclaimed lands of the coastal areas. Here, groundwater lies very close to the surface (Velstra et al. 2009), and productive agricultural systems may be increasingly reliant on freshwater from surface waters for production (Nillesen and van Ierland 2006). In future, such lands would require sufficient flushing with freshwater in order to keep the saline interface at bay. Faced with ever increasing sea level-induced pressures from below, and the potential for less rainfall or more freshwater abstraction from above, keeping the saline interface at sufficient depth will prove to be a challenge for Dutch agriculture in the 21st century (Velstra et al. 2009).

\subsubsection{Germany}

Following global sea level rise in the Holocene, salinization of the German North Sea coast stretched up to $20 \mathrm{~km}$ inland (Martens and Wichmann 2011). Centuries of storm surges, land reclamation and extensive dike building created the current German North Sea coastline we see today (Vollmer et al. 2001). It stretches about $1,300 \mathrm{~km}$ (including islands), with a closed dike line offering protection for the land behind. Without these dikes, in some places up to 9 metres in height, and coastal protection system, the low-lying hinterland would be flooded with the tides. Large areas of the region lie below sea level and the coastline is vulnerable in a changing climate (Sterr 2008). 
The most vulnerable regions to groundwater salinization are the barrier islands, such as the East Frisian Islands (Figure 5.3d) (Röper et al. 2012; Seibert et al. 2018), and the low-lying marsh lands such as East Frisia. In these regions, German agriculture is threatened by flood inundation during storm surges, which can lead to rapid salinization of groundwater lenses (islands) or groundwater aquifers (mainland); whilst increasing seawater pressure and decreasing freshwater resources lead to comparatively slower seepage salinization (Werner et al. 2013). Recovery of infiltrated freshwater bodies in such areas takes years to decades (Anderson 2002; Holding and Allen 2015; Post and Houben 2017).

Groundwater in parts of North Germany's coastal areas is also subject to the "coastal groundwater squeeze" (Daliakopoulos et al. 2016; Michael et al. 2017) and as such, salinization of groundwater resources in Northern Germany becomes a growing issue for public water supply. Although currently much of the groundwater monitoring focuses on other anthropogenic inputs such as nitrates and pesticides, in the long-term groundwater salinization is expected to become a critical threat to the utilization of groundwater sources (Grube, 2000). The situation is exacerbated by increasing population, tourism and general water demand (Michael et al. 2017) and consequences of sea level rise, flooding and droughts (Jurasinski et al. 2018).

\subsubsection{Denmark}

The Danish coastline stretches 7,400 km from the North Sea in the west to the Baltic in the east, comprising the Jutland peninsula alongside hundreds of islands, exposed to a gradient of salinity from west to east (Hansen et al. 2011). With a few exceptions of land reclamation by dike construction in fjords, such as Lammefjorden in 1873, the landscape of Denmark is generally above mean sea level. The southern part of the North Sea coast of Jutland constitutes the northern extent of the Wadden Sea and marshes protected from flooding by dikes established in the past 100 years. North of Esbjerg the coast is protected by an extensive belt of sand dunes. This belt of sand dunes has been subject to significant erosion during the past 50 years and in major sections is only maintained by protective initiatives such as beach enrichment and repetitive reshaping of the remaining sand dune barrier. Flooding in Denmark falls into two categories: flooding in the marsh of the North Sea coast is a rare event with only limited effects during the past 100 years, while flooding of coasts in the inner sea (Baltic Sea and Kattegat) including flooding of arable land is reported with increasing frequency.

Groundwater salinity in Denmark is currently monitored in sources of drinking water. An increase in salinity has been seen in coastal regions, most significantly in coasts of the inner sea including Zealand and small islands such as Læs $\varnothing$, Endelave, Sejerø (Figure 5.4a) (summarized by Kristiansen et al. 2011). These areas also correspond with reported areas of saline intrusion noted by Fenger et al. (2008). There is also evidence in Danish coastal regions of legacy impacts of sea spray on forest soils (Pedersen and Bille-Hansen 1995), suggesting airborne salinity as another potential pathway of salinization in coastal Denmark. Root zone soil salinity has only recently been subject to study in Denmark (Christensen 2021), which revealed that there is no accumulation of marine salt in soil in Denmark, most likely due to flushing from 


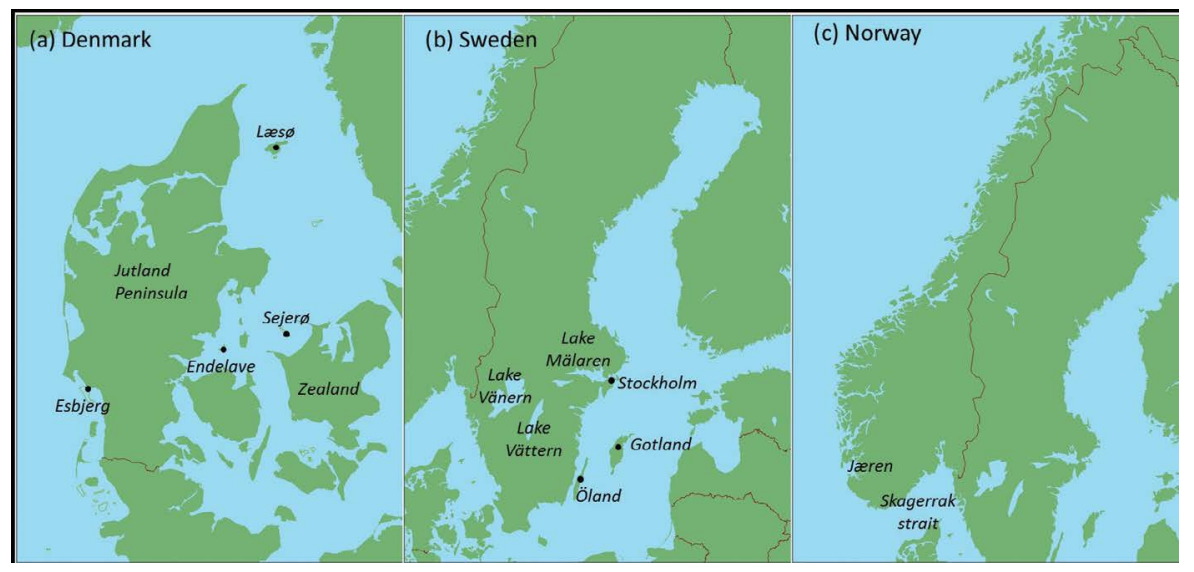

FIGURE 5.4 Locations discussed in Denmark (a); Sweden (b); Norway (c).

sufficient rainfall. However, temporary soil salinity can be observed as a result of flood or seepage from the coast as well as aerosol from the sea.

The Danish case also offers an historic insight into how local communities can adapt to, and even exploit, salinization for economic benefit. Saline groundwater on the island of Læsø (Jørgensen 2002) allowed large-scale production of salt on the island between the 12th and 16th centuries, bringing wealth to the island, salt being an essential commodity for food preservation in Scandinavia and Northern Europe.

\subsubsection{SWEDEN}

Groundwater salinization in Sweden has been explored in several studies, most of which date back to the late 1980s and early 1990s. The most comprehensive works (Knutsson and Fagerland 1977; Lindewald 1981; Olofsson 1996) investigating the occurrence of groundwater salinization in Sweden utilize data sourced from the Geological Survey of Sweden (SGO). According to Olofsson (1996), groundwater salinization in Sweden is attributed to several factors including the intrusion of seawater in coastal areas, fossil seawater, chemical interaction between the groundwater and the aquifer, as well as anthropogenic sources such as runoff from waste deposits and the use of de-icing salts on roads.

Lindewald (1981) presented evidence of groundwater salinity in Sweden using data from the SGO. The results showed that 780 wells were identified as salinized, with Chloride concentrations of 300-7000 mg per litre. In a later study by Olofsson (1996), as many as 13,000 wells were said to have a "salty taste", with Chloride levels of $300 \mathrm{mg} / \mathrm{L}$ or higher. The majority of wells exhibiting salinity could be found along the whole Swedish coastline (including Öland and Gotland), and into central Sweden within a $200 \mathrm{~km}$ wide zone from the Swedish west coast via Lake Vänern, and from Lake Vättern to Lake Mälaren near Stockholm (Figure 5.4b) (Olofsson 1996). Saline groundwater occurred in different aquifers in Sweden and could be found in sedimentary as well as in crystalline bedrock as well as in sand and gravel 
deposits (Lindewald 1981). Lindewald (1981) linked the cause of salinization on the west coast with the transgression from the Atlantic Ocean.

Approximately $1,800 \mathrm{~km}$ of the Swedish coast is at risk of climate-driven erosion, land degradation, loss of natural habitats, and infrastructure depreciation (SOU 2007). The coast of Southern Sweden is particularly exposed to erosion and coastal flooding; which are expected to increase in the coming 100 years (SOU 2007). Like much of the North Sea region, sea level rise in combination with increasing demand on groundwater may intensify the salinization of groundwater along with the coastal areas of Sweden bordering the North Sea.

\subsubsection{NORWAY}

Unlike many other North Sea countries, groundwater only plays a relatively small, although increasing, role in Norway's drinking water supply on account of the large reserves of surface water available (NGU 2014). Groundwater is thus not monitored in as much detail as in some other countries, resulting in limited data for groundwater salinity measures. As a result also, seawater intrusion of groundwater has seen little attention in monitoring and research. However, despite a generally low awareness concerning potential agricultural problems related to seawater intrusion, the Geological Survey of Norway lists reducing groundwater removal to avoid saltwater intrusion in coastal areas among possible measures to maintain good groundwater quality.

For Norway, climate-driven sea level rise will dominate over land subsidence in the coming century, although predicted sea level changes are expected to be below the global mean (Simpson et al. 2015). Coastal areas in South-Western and Western Norway will most likely experience larger relative sea level increases than in more northerly areas (with the exceptions of some islands) or in the Skagerrak strait (Simpson et al. 2015). In terms of potential salinization of agricultural land, though the risk may be low in general, some areas along the North Sea coast may be prone to saline inundation, as well as saline intrusion into groundwater, as reflected by high electrical conductivities and salt concentrations measured in a coastal location within the national groundwater surveillance grid (Orresanden; Seither et al. 2016). One of these areas is Jæren in South West Norway (Figure 5.4c), the country's largest lowland plain with significant agricultural production. While agricultural land in this region mainly remains several metres above sea level, extreme storm surges may still flood farmland (Eich-Greatorex et al. 2020).

Future salinization threats in Norway may thus manifest from inundation due to storm events, and also aerosol and seepage salinization may be relevant in some areas. Additionally, interest in irrigation with brackish water is rising. However, Norway will likely be one of the least impacted nations in the North Sea region.

\subsection{DISCUSSION}

It is clear from the exploration of our country case studies that even in a region of relatively similar climatic conditions, the issue of salinization is diverse and complex. Nevertheless, the country studies do highlight some common themes - namely that sea 
level rise, and increased demand for freshwater, will induce pressures on groundwater resources across the coastal region. As such, seepage salinization will manifest and could either lead to increased salinity in the root zone, for example in the Netherlands, Denmark or Belgium where evidence shows saline groundwater is relatively shallow in the soil profile; or by upward movement of saline water mixing with surface waters or irrigation sources. Despite all countries facing some degree of seepage salinization, it is the relatively slow nature of seepage salinization, in comparison to flooding, which provides one of the major policy challenges facing the region. Subsequent impacts take time, and may not become evident for many years. Therefore, the problem may be classified as a "creeping catastrophe" (Schneider et al. 2013) posing challenges to a better understanding of its dimensions and societal responses.

Unlike seepage, current flood salinization threats differ vastly between counties in the region as a result of geographical and management factors. Countries that have invested more in coastal defences, such as the Netherlands, or have mainly higher and steeper topography, such as Norway, are unlikely to see much flood salinization at present, although a future risk to these countries should not be ruled out. The Netherlands further offers us an example of how strategic investment can help reduce flood salinization risks; although this comes at substantial financial cost. Conversely, the mechanisms of salinization to the UK, Germany and Denmark are manifold: these countries have experienced flooding in recent history; are likely confronting the "coastal groundwater squeeze" (Michael et al. 2017), and have been subject to the airborne deposition of salts. Taking this all into account portrays a very complex picture throughout the North Sea region, highlighting the interdisciplinary nature required to address the future salinization challenge.

Of the four mechanisms outlined in the framework (Figure 5.2), irrigation salinization may be a likely pathway of future salinization, but not something of present concern given the lack of existing data on the subject. However, whilst conducting this review, and the wider SalFar project, we noted some curiosity and willingness from growers to explore new opportunities with brackish water irrigation across the region, and several anecdotal reports of such practices. For growers, brackish water irrigation may lead to reductions in water costs, or saving viable crops in times of drought. Much of the data on the salt tolerance of conventional crops has emerged from trials in more arid regions, and on older varieties (Ayers and Westcot 1985; Tanji and Kielen 2002). More research is needed to identify whether such crops may be able to withstand more salinity than first thought, if grown in a climate of more precipitation such as the North Sea region. Recent work on the island of Texel in the Netherlands has explored salt tolerance of conventional crops commonplace in European agriculture (de Vos et al. 2016). Their findings, albeit conducted in a sandy soil environment with greater flushing rates, suggest that several typical crops may withstand more salinity in their irrigation water than first thought. However, such practices are not without risk. The potential for long-term soil damage from brackish irrigation in maritime climates remains unknown. Further investigation with longterm salinity field trials is required in order to explore both crop impact and the soil physical, chemical and biological response under a range of different management regimes. 
What is evident from our exploration of the North Sea region is not only a general lack of sufficient data on salinity, but also an inconsistency of measurement between countries. In the Danish islands, we obtained data on percentage (\%) salinity. In Belgium, saline groundwater data has been reported in $\mathrm{g} / \mathrm{L}$ total dissolved solids. In other countries, monitoring of Chloride levels is more routine for water companies. Many farmers and growers use portable and commercial probes to measure salinity in units of ppm. Across all countries, data on water salinity was more available than soil data. The lack of data and consistency between nations is not unsurprising, given that salinization has been of little historic concern in the region compared to other parts of the world. However, over the coming century the issue of salinity will become ever more prescient, and systematic monitoring, mapping and data collection, consistent across all countries of the region, will be essential if the region is to adapt to such threats.

Despite the complexity around the region, and the lack of available data, we predict increased occurrence of salinization to the region in the coming century. Faced with this, coastal land management and agriculture will need to adapt. Key to this will be the complex role of water management bodies. A combination of coastal protection, groundwater abstraction regulation, drainage networks and attenuation and storage areas already constitute much of the North Sea region's multifaceted approach to coastal land management. This will become ever more critical in the coming century, where sea level rise will put greater demands on coastal defences, freshwater abstraction rates will see greater demand in times of water scarcity, and approaches to drainage and pumping will need to address seasonal water shortages. An example of one possible solution might be the designation of water retention areas, both above and below surface, in order to store water instead of pumping it into the North Sea, e.g. large attenuation areas or irrigation reservoirs. In doing this, excess freshwater over winter can be retained to later supply irrigation in the summer months (Karrasch et al. 2017).

Without investment in water management and protection, farmers may need to explore adaptations. Whether it be extending rotation and introducing more grazing, or growing more salt tolerant crops, potentially even halophytes (Rozema and Schat 2013), coastal growers will need to make evidence-based decisions. As such, the potential for "Saline Agriculture" (Ladeiro 2012) - food production that accepts, and adapts to, a degree of salinity in the system - requires further investigation from the research, policy and agricultural communities. In each context, however, we must remember that farmers' decision-making is also complex. Scientists and economists may develop models that suggest optimal choices based on salinization-risk and market analyses, but local traditions, social networks and family imperatives all shape behaviour in different ways. Some of these personal factors will influence a farmer's willingness to innovate, impacting on their "perceived room for manoeuvre" (Methorst et al. 2017). Other factors will see strategic changes emerging from a range of other sources, including both local networks and extensive supply chain connections, thus the communication of science and policy must engage a diversity of networks in order to bring about behavioural change. 


\subsection{CONCLUSION}

Unlike the arid and semi-arid regions, there is limited data available on salinization, or its potential, in the North Sea region. However, under future climate projections, we anticipate the risk of salinization to agriculture in the region to dramatically increase. The risks and mechanisms of salinization across all North Sea nations are extremely diverse and can vary greatly from one country to another. If the region is to develop resilience to salinization in our agricultural systems, it requires more comprehensive knowledge about salinization. This could be realized through more extensive mapping and monitoring, and further research into how farms can respond and adapt, potentially opening greater scope for "saline agriculture".

\section{ACKNOWLEDGMENTS}

This review was funded as part of the Interreg VB North Sea Region programme as part of the SalFar project, and the authors would like to thank all SalFar partners, in addition to the multiple farmers, stakeholders and other practitioners we have worked with around the North Sea region. We would also like to thank Carole Ampe (Flemish Land Agency, VLM) for reviewing an earlier version of the manuscript. The authors also gained valuable knowledge from the SALTSA project (supported by the DFG, grant number GZ: SI 728/5-1). We also thank the anonymous reviewers for comments on an earlier draft.

\section{REFERENCES}

Abrol, I. P., Yadav, J. S. P., and Massoud, F. I. 1988. Salt-affected soils and their management. In: Soils Bulletin. FAO Rome, Italy.

Agovino, M., Casaccia, M., Ciommi, M., Ferrara, M., and Marchesano, K. 2019. Agriculture, climate change and sustainability: The case of EU-28, Ecological Indicators 105: 525-543. https://doi.org/10.1016/j.ecolind.2018.04.064

Anderson, W. P. 2002. Aquifer salinisation from storm overwash. Journal of Coastal Research 18(3): 413-420.

Ayers, R. S., and Westcot, D. W. 1985. Water quality for agriculture. FAO Irrigation and drainage paper (29) Rev. 1

Balance, J. A., and Duncan, J. R. 1985. Wind-borne transport and deposition of sea-salt in New Zealand. New Zealand Journal of Technology 1: 239-244.

Baxter, P. J. 2005. The east coast big flood, 31 January-February 1, 1953: A summary of the human disaster. Philosophical Transactions of the Royal Society A: Mathematical, Physical and Engineering Sciences 363(1831): 1293-1312. https://doi.org/10.1098/ rsta.2005.1569

Beauchampet, I. C. 2019. Salinization and agriculture in the Netherlands: benchmarking stakeholder perspectives. MSc Environment and Resource Management, Vrije Univeriteit Amsterdam, September 2019. https://www.waddenacademie.nl/fileadmin/ inhoud/pdf/06-wadweten/Scripties/Beauchampet_Salinization_NL.pdf

Brecht, H., Dasgupta, S., Laplante, B., Murray, S., and Wheeler, D. 2012. Sea- level rise and storm surges. The Journal of Environment \& Development 21(1): 120-138. https://doi. org/10.1177/1070496511433601

Bodirsky, B. L., Rolinski, S., Biewald, A., Weindl, I., Popp, A., and Lotze-Campen, H. 2015. Global food demand scenarios for the 21st century. PLoS ONE 10(11): e0139201. https:// doi.org/10.1371/journal.pone.0139201 
Bouwer, L., and Vellinga, P. 2007. On the flood risk in the Netherlands. In: Begum, S., Stive, M. J. F., Hall, J.W. (eds) Flood Risk Management in Europe. Advances in Natural and Technological Hazards Research, vol 25. Springer, Dordrecht. https://doi. org/10.1007/978-1-4020-4200-3_24

Christensen, L. S. (2021) Dynamics of soil salinity in Denmark. This present book.

CIW. 2018. Evaluatierapport waterschaarste en droogte 2017, report by Coördinatiecommissie Integraal Waterbeheer (CIW), available at www.integraalwaterbeleid.be

CIW. 2019. Evaluatierapport waterschaarste en droogte 2018, report by Coördinatiecommissie Integraal Waterbeheer (CIW), available at www.integraalwaterbeleid.be

CIW. 2020. Evaluatierapport waterschaarste en droogte 2019, report by Coördinatiecommissie Integraal Waterbeheer (CIW), available at www.integraalwaterbeleid.be

Cooper, D., Foster, C., Gooday, R., Hallett, P., Hobbs, P., Irvince, B., Kirkby, M., Morrow, K., Ragab, R., Rawlins, B., Richards, M., Smith, P., Spurgeon, D., and Tye, A. 2010. Modelling the impact of climate change on soils using UK climate projections. Scientific Report. DEFRA Project SPo571

Cui, G., Lu, Y., Zheng, C., Liu, Z., and Sai, J. 2019. Relationship between soil salinization and groundwater hydration in Yaoba Oasis, Northwest China. Water 11:175. doi:10.3390/ w11010175

Daliakopoulos, I., Tsanis, I., Koutroulis, A., Kourgialas, N., Varouchakis, A., Karatzas, G., and Ritsema, C. J. 2016. The threat of soil salinity: A European scale review. Science of the Total Environment 573: 727-739.

de Louw, P. G. B., Essink, G. O., Stuyfzand, P. J., and Van der Zee, S. E. A. T. M. 2010. Upward groundwater flow in boils as the dominant mechanism of salinization in deep polders, The Netherlands. Journal of Hydrology 394(3-4): 494-506.

de Louw, P. G. B., Eeman, S., Siemon, B., Voortman, B. R., Gunnink, J., van Baaren, E. S., and Oude Essink, G. H. P. 2011. Shallow rainwater lenses in deltaic areas with saline seepage. Hydrology and Earth System Sciences 15: 3659-3678. doi:10.5194/ hess-15-3659-2011

de Louw, P. G. B. 2013. Saline seepage in deltaic areas: Preferential groundwater discharge through boils and interactions between thin rainwater lenses and upward saline seepage (Doctoral dissertation). Vrije Universiteit, Amsterdam, the Netherlands.

de Vos, A., Bruning, B., van Straten, G., Oosterbaan, R., Rozema, J., and van Bodegom, P. 2016. Crop salt tolerance under controlled field conditions in The Netherlands based on trials conducted at Salt Farm Texel. December 2016, Salt Farm Texel, Den Berg.

De Waegemaeker, J. 2019. SalFar framework on salinization processes. A comparison of salinization processes across the North Sea Region, a report by ILVO for the Interreg VB North Sea Region project Saline Farming (SalFar).

Delsmans, J., van Baaren, E., Vermaas, T., Karaoulis, M., Bootsma, H., de Louw, P., Pauw, P., Oude Essink, G., Dabekaussen, W., Van Camp, M., Walraevens, K., Vandenbohede, A., Teilmann, R., and Thofte, S. 2019. TOPSOIL Airborne EM kartering van zoet en zout grondwater in Vlaanderen (FRESHEM Vlaanderen), A report for the Flemish Environmental Agency (VMM), Aalst.

Durant, D., Kernéîs, E., Meynard, J-M., Chosis, J. P., Chataigner, C., Hillaireau, J-M., and Rossignol, C. 2018. Impact of storm Xynthia in 2010 on coastal agricultural areas: The Saint Laurent de la Prée research farm's experience. Journal of Coastal Conservation 22: 1177-1190. https://doi.org/10.1007/s11852-018-0627-8

Eich-Greatorex, S., Malesevic, T., and Almås, ÅA. R. 2020. Sea level rise and potential impact of saltwater on agriculture along the Norwegian North Sea coast - Case study Jæren. MINA/NMBU report, in prep.

Endo, T., Yamamoto, S., Larringa, J., Fujiyama, H., and Honna, T. 2011. Status and causes of soil salinization of irrigated agricultural lands in Southern Baja California, Mexico. Applied and Environmental Soil Science. http://dx.doi.org/10.1155/2011/873625 
Environment Agency. 2020. Meeting our Future Water Needs: A National Framework for Water Resources. 16 March 2020, Version 1. Environment Agency, Bristol.

European Environment Agency. 2019. Global and European sea-level rise. Indicator Assessment. European Environment Agency. Copenhagen, Denmark.

FAO. 2015. Status of the World's Soil Resources Food and Agriculture Organisation of the United Nations Rome, Italy.

Fagherazzi, S., Anisfeld, S. C., Blum, L. K., et al. 2019. Sea level rise and the dynamics of the marsh-upland boundary. Frontiers in Environmental Science 7. 10.3389/ fenvs.2019.00025

Fenger, J., Buch, E., Jakobsen, P., and Vestergaard, P. 2008. Danish attitudes and reactions to the threat of sea-level rise. Journal of Coastal Research 24(2): 394-402.

Foley, J., Ramankutty, N., Brauman, K., et al. 2011. Solutions for a cultivated planet. Nature 478: 337-342. https://doi.org/10.1038/nature10452

Franzén, L. 1990. Transport, deposition and distribution of marine aerosols over southern Sweden during dry westerly storms. Ambio 19(4): 180-188.

Gerritsen, H. 2005. What happened in 1953? The Big Flood in the Netherlands in retrospect. Philosphical Transaction of the Royal Society A 3631271-1291. http://doi.org/10.1098/ rsta.2005.1568

Gould, I. J., Wright, I., Collison, M., Ruto, E., Bosworth, G., Pearson, S. 2020. The impact of coastal flooding on agriculture: A case- study of Lincolnshire, United Kingdom. Land Degradation and Development 1-15. https://doi.org/10.1002/ldr.3551

Grube, A. T. 2000. Geogene Grundwasserversalzung in den Poren-Grundwasserleitern Norddeutschlands und ihre Bedeutung für die Wasserwirtschaft, DVGWTechnologiezentrum Wasser (TZW).

Gustafsson, M., and Franzen, L. 1996. Dry deposition and concentration of marine aerosols in a coastal area, SW Sweden. Atmospheric Environment 30(6): 977-989.

Hansen, J. W., Windelin, A., Göke, C., et al. 2011. Notat 1.1 - Fysiske og kemiske forhold. DCE - Nationalt Center for Miljø og Energi, Aarhus Universitet. Notat udarbejdet for Naturstyrelsen

Hazelden, J., and Boorman, L. A. 2001. Soils and 'managed retreat' in south east England. Soil Use and Management 17: 150-154.

Hickey, K. R. 1997. Documentary records of coastal storms in Scotland 1500-1991 A.D. Volume 1. Unpublished Thesis. Coventry, UK:Coventry University. Accessed https:// curve.coventry.ac.uk/open/file/aa6dfd04-d53f-4741-1bb7-bdf99fb153be/1/hick1comb. pdf

Hodgkinson, R. A., and Thorburn, A. A. 1995. Factors influencing the stability of salt affected soils in the UK - criteria for identifying appropriate management options. Agricultural Water Management 29: 327-338.

Hoeksema, R. J. 2007. Three stages in the history of land reclamation in the Netherlands. Irrigation and Drainage 56: S113-S126. doi:10.1002/ird.340

Holding, S., and Allen, D. M. 2015. Wave overwash impact on small islands: Generalised observations of freshwater lens response and recovery for multiple hydrogeological settings. Journal of Hydrology, 529: 1324-1335.

Huisman, P., Cramer, W., Van Ee, G., Hooghart, J. C., Salz, H., and Zuidema, F. C. 1998. Water in the Netherlands. Netherlands Hydrological Society, Rotterdam.

IPCC. 2019. The Ocean and Cryosphere in a Changing Climate. Accessed 26th October 2019 at: https://report.ipcc.ch/srocc/pdf/SROCC_SPM_Approved.pdf

Jones, A., Panagos, P., Barcelo, S., et al. 2012. The state of soil in Europe. A Contribution of the JRC to the European Environment Agency's Environment State and Outlook Report (European Commission: Luxembourg) Available at https://ec.europa.eu/ $\mathrm{jrc/en/publication/reference-reports/state-soil-europe-contribution-jrc-european-}$ environment-agency-s-environment-state-and-outlook 
Jørgensen, N. 2002. Origin of shallow saline groundwater on the Island of Læsø, Denmark. Chemical Geology 184: 359-370. 10.1016/S0009-2541(01)00392-8.

Jurasinski, G., Janssen, M., Voss, M., Böttcher, M. E., Brede, M., Burchard, H., et al. 2018. Understanding the coastal ecocline: Assessing sea-land-interactions at non-tidal, lowlying coasts through interdisciplinary research. Frontiers in Marine Science 5: 342.

Karrasch, L., Maier, M., Kleyer, M., and Klenke, T. 2017. Collaborative landscape planning: Co-design of ecosystem-based land management scenarios. Sustainability 9(9): 1668.

Knutsson, G., and Fagerland, T. 1977. Grundvattentillgångar i Sverige (Groundwater resources in Sweden), SGU.

Kristiansen, S. M., Christensen, F. D., and B. Hansen, B. 2011. Does road salt affect groundwater in Denmark? Geological Survey of Denmark and Greenland Bulletin 2: 45-48. Open Access: www.geus.dk/publications/bull

Ladeiro, B. 2012. Saline agriculture in the 21st century: Using salt contaminated resources to cope food requirements. Journal of Botany 1-7. doi:10.1155/2012/310705

Lebbe, L., Van Meir, N., and Viane, P. 2008. Potential implications of sea-level rise for Belgium. Journal of Coastal Research 24(2): 358-366

Lindewald, H. 1981 Saline groundwater in Sweden. Intruded and relict groundwater of marine origin, 7th Salt-Water Intrusion Meeting, 1981. 24-32

Liski, A. H., Ambros, P., Metzger, M. J., Nicholas, K. A., Wilson, A. M. W., and Krause, T. 2019. Governance and stakeholder perspectives of managed re-alignment: Adapting to sea level rise in the Inner Forth estuary, Scotland. Regional Environmental Change 19:2231-2243. https://doi.org/10.1007/s10113-019-01505-8

Loveland, P., Hazelden, J., Sturdy, R., and Hodgson, J. 1986, Salt- affected soils in England and Wales. Soil Use and Management 2: 150-156. doi:10.1111/j.1475-2743.1986. tb00700.x

MacAllister, D. J., Jackson, M. D., Butler, A. P., and Vinogradov, J. 2018. Remote detection of saline intrusion in a coastal aquifer using borehole measurements of self- potential. Water Resources Research 54: 1669- 1687. https://doi.org/10.1002/2017WR021034

Manca, F., Capelli, G., and Tuccimei, P. 2015. Sea salt aerosol groundwater salinization in the Litorale Romano Natural Reserve (Rome, Central Italy). Environmental Earth Sciences 73: 4179-4190

Martens, S., and Wichmann, K. 2011. Grundwasserversalzung in Deutschland. In: WARNSIGNAL KLIMA: Genug Wasser für alle? 3.Auflage- Hrsg. Lozán, JLH, Graßl, P, Hupfer, L, Karbe \& Schönwiese, CD: 203-207.

Masterson, J. P., and Garabedian, S.P. 2007. Effects of sea- level rise on ground water flow in a coastal aquifer system. Groundwater 45: 209-217. doi:10.1111/j.1745-6584. 2006.00279.x

Mayes, J., and Wheeler, D. 2013. Regional weather and climates of the British Isles - Part 1: Introduction. Weather 68: 3-8. doi:10.1002/wea.2041

McCune, D. C. 1991. Effects of airborne saline particles on vegetation in relation to variables of exposure and other factors. Environmental Pollution 74(3): 176-203.

Methorst, R. G., Roep, D., Verhees, F. J. H. M., and Verstegen, J. A. A. M. 2017. Differences in farmers' perception of opportunities for farm development. NJAS - Wageningen Journal of Life Sciences 81: 9-18. https://doi.org/10.1016/j.njas.2017.02.001

Michael, H. A., Post, V. E., Wilson, A. M., and Werner, A. D. 2017. Science, society, and the coastal groundwater squeeze. Water Resources Research 53(4): 2610-2617.

National Farmers Union (2013). Briefing. December 2013 tidal surge floods - Agricultural impact. Version 2. Retrieved from https://www.nfuonline.com/assets/21657

NGU, Geological Survey of Norway. 2014. Groundwater. Accessed 19 December 2018 from http://www.miljostatus.no/tema/ferskvann/grunnvann/Rapport. In Norwegian.

Nicholls, R. J., and Cazenave, A. 2010. Sea- level rise and its impact on coastal zones. Science 328(5985): 1517-1520. https://doi.org/10.1126/science.1185782 
Nillesen, E. E. M., and E. C. van Ierland (eds), 2006. Climate change scientific assessment and policy analysis. Climate adaptation in the Netherlands. Report Wageningen UR $500102003,118$.

O'Dowd, C., and de Leeuw, G. 2007. Marine aerosol production: A review of the current knowledge. Philosophical Transactions of the Royal Society of London. A 365:1753-1774.

Olofsson, B. 1996. Salt groundwater in Sweden - occurrence and origin. Salt Water Intrusion Meeting (SWIM). 16-21.

Oude Essink, G. H. P. 2001. Improving fresh groundwater supply - problems and solutions. Ocean and Coastal Management 44: 429-449

Oude Essink, G. H. P., van Baaren, E. S., and de Louw, P. G. B. 2010. Effects of climate change on coastal groundwater systems: A modeling study in the Netherlands. Water Resources Research 46: W00F04. doi:10.1029/2009WR008719

Paes, J. L. d. A., Ruiz, H. A., Fernandes, R. B. A., Freire, M. B. G. d. S., Barros, M. d. F. C., and Rocha, G.C. 2014. Hydraulic conductivity in response to exchangeable sodium percentage and solution salt concentration. Revista Ceres 61: 715-722.

Palmer, T., and Räisänen, J. 2002. Quantifying the risk of extreme seasonal precipitation events in a changing climate. Nature 415: 512.

Pedersen, L. B., and Bille-Hansen, J. 1995. Effects of airborne sea salts on soil water acidification and leaching of aluminium in different forest ecosystems in Denmark. In: Nilsson, L. O., Hüttl, R. F., Johansson, U. T. (eds) Nutrient Uptake and Cycling in Forest Ecosystems. Developments in Plant and Soil Sciences, vol 62. Springer, Dordrecht.

Pendergrass, A. G., Knutti, R., Lehner, F., et al. 2017. Precipitation variability increases in a warmer climate Scientific Reports 7: 17966. https://doi.org/10.1038/s41598-017-17966-y

Pitman, M. G., and Läuchli, A. 2002. Global impact of salinity and agricultural ecosystems. In: Läuchli, A., Lüttge, U. (eds) Salinity: Environment - Plants - Molecules. Springer, Netherlands Dordrecht, 3-20.

Post, V. E., and Houben, G. J. 2017. Density-driven vertical transport of saltwater through the freshwater lens on the island of Baltrum (Germany) following the 1962 storm flood. Journal of Hydrology 551: 689-702.

Qadir, E. Quillérou, Nangia, V., et al. 2014. Economics of salt-induced land degradation and restoration. Natural Resources Forum 38: 282-295.

Raats, P. A. C. 2015 Salinity management in the coastal region of the Netherlands: A historical perspective. Agricultural Water Management 157: 12-30. https://doi.org/10.1016/j. agwat.2014.08.022

Rath, K. M., and Rousk, J. 2015. Salt effects on the soil microbial decomposer community and their role in organic carbon cycling: A review. Soil Biology and Biochemistry 81: $108-123$.

Rengasamy, P. 2006. World salinization with emphasis on Australia. Journal of Experimental Botany 57 (5): 1017-1023. https://doi.org/10.1093/jxb/erj108

Rey, D., Holman, I. P., Daccache, A., Morris, J., Weatherhead, E. K., and Knox, J. W. 2016. Modelling and mapping the economic value of supplemental irrigation in a humid climate. Agricultural Water Management 173: 13-22. https://doi.org/10.1016/j. agwat.2016.04.017.

Roberts, L. R., Sayer, C. D., Hoare, D., et al. 2019. The role of monitoring, documentary and archival records for coastal shallow lake management. Geography and Environment e00083. https://doi.org/10.1002/geo2.83.

Röper, T., Kröger, K. F., Meyer, H., Sültenfuss, J., Greskowiak, J., and Massmann, G. 2012. Groundwater ages, recharge conditions and hydrochemical evolution of a barrier island freshwater lens (Spiekeroog, Northern Germany). Journal of Hydrology 454: 173-186.

Rozema, J., and Schat, H. 2013. Salt tolerance of halophytes, research questions reviewed in the perspective of saline agriculture. Environmental and Experimental Botany 92: 83-95. doi:10.1016/j.envexpbot.2012.08.004. 
Rowell, D. P., and Jones, R. G. 2006. Causes and uncertainty of future summer drying over Europe. Climate Dynamics 27: 281-299.

Rozema, J., Van Manen, Y., Vugts, H. F., and Leusink, A. 1983. Airborne and soilborne salinity and the distribution of coastal and inland species of the genus Elytrigia. Acta Botanica Neerlandica 32: 447-456.

Salehin, M., et al. (2018) Mechanisms and drivers of soil salinity in coastal Bangladesh. In: Nicholls, R., Hutton, C., Adger, W., Hanson, S., Rahman, M., Salehin, M. (eds) Ecosystem Services for Well-Being in Deltas. Palgrave Macmillan, Cham.

Schneider, V., Leifeld, P., and Malang, T. 2013. Coping with creeping catastrophes: National political systems and the challenge of slow-moving policy problems. In: Siebenhner, B., Arnold, M., Eisenack, K., and Jacob, K. H. (eds) Long-Term Governance of SocialEcological Change. Series: Environmental politics (21). Routledge, New York, pp. 221-238. ISBN 9780415633529

Seibert, S. L., Holt, T., Reckhardt, A., et al. 2018. Hydrochemical evolution of a freshwater lens below a barrier island (Spiekeroog, Germany): The role of carbonate mineral reactions, cation exchange and redox processes. Applied Geochemistry 92: 186-208.

Seither, A., Gundersen, P., Jæger, Ø., and Sæther, O. M. 2017. Nationwide Soil Water and Groundwater Observation Network (LGN) - Past and future after 39 years of operation. NGU-Report no. 2016.039, ISSN: 2387-3515 (online). In Norwegian.

Simpson, M., Nilsen, J. E., Ravndal, O.,et al. 2015. Sea Level Change for Norway: Past and Present Observations and Projections to 2100. 10.13140/RG.2.1.2224.9440.

SOU 2007. Swedish Official Report on Climate and Vulnerability. Regeringskansliet, Stockholm. 60.

Spencer, T., Brooks, S. M., Evans, B. R., Tempest, J. A., and Möller, I. 2015. Southern North Sea storm surge event of December 5, 2013: Water levels, waves and coastal impacts. Earth-Science Reviews 146: 120-145. https://doi.org/10.1016/j.earscirev.2015.04.002

Steers, J. A., Stoddart, D. R., Bayliss-Smith, T. P., Spencer, T., and Durbidge, P. M. 1979. The storm surge of January 11, 1978 on the East Coast of England. The Geographical Journal 145(2): 192-205. https://doi.org/10.2307/634386

Sterr, H. 2008. Assessment of vulnerability and adaptation to sea-level rise for the coastal zone of Germany. Journal of Coastal Research, 380-393.

Stofberg, S. F., Essink, G. H. P. O., Pauw, P. S., et al. 2017. Fresh Water Lens Persistence and Root Zone Salinization Hazard under Temperate Climate. Water Resource Management 31: 689-702. https://doi.org/10.1007/s11269-016-1315-9

Tabari, H., Taye, M. T., and Willems, P. 2015. Actualisatie en verfijning klimaatscenario 's tot 2100 voor Vlaanderen - Appendix 2: Nieuwe modelproject voor Ukkel op basis van globale klimaatmodellen (CMIP5) en actualisatie klimaatscenario's, p.107, a report by KU Leuven for Vlaamse Milieumaatschappij, Aalst

Tanji, K., and Kielen, N. C. 2002. Agricultural Drainage Water Management in Arid and Semi-arid Areas. FAO, Italy.

Tavernier, R., Ameryckx, J., Snacken, F., and Farasyn, D. 1970. Atlas van België blad 17 Kust, Duinen, Polders, p. 32, a report by Nationaal Comité voor Geografie (Commissie voor de Nationale Atlas), Brussels.

Tóth, G., Montanarella, L., and Rusco, E. 2008. Threats to Soil Quality in Europe. EUR 23438 EN. Institute for Environment and Sustainability, Land Management and Natural Hazards Unit, Office for the Official Publications of the European Communities, Luxembourg.

United Nations Department of Economic and Social Affairs, Population Division. 2017. World Population Prospects: The 2017 Revision, DVD Edition.

Vandenbohede, A., Courtens, C., Lebbe, L., and de Breuck, W. 2010. Fresh-salt water distribution in the central Belgian coastal plain: An update. Geologica Belgica 13(3): $163-172$. 
Vandenbohede, A., Walraevens, K., and De Breuck, W. 2015. What does the interface on the fresh - saltwater distribution map of the Belgian coastal plain represent? Geologica Belgica 18(1): 31-36.

Velstra J., Hoogmoed M., and Groen, K. 2009. Inventarisatie maatregelen omtrent interne verzilting. In: Leven met zout water (203). Acacia Water.

VMM (2014) Verziltingskaart Vlaanderen, dataset by Vlaamse Milieumaatschappij, Aalst, available online at dov.vlaanderen.be

Vollmer, M., Guldberg, M., Maluck, M., Marrewijk, D., and Schlicksbier, G. 2001. Landscape and cultural heritage in the Wadden Sea Region - Project report. Wadden Sea Ecosystem No. 12. Common Wadden Sea Secretariat, Wilhelmshaven.

Vousdoukas, M. I., Voukouvalas, E., Annunziato, A., Giardino, A., and Feyen, L. 2016. Projections of extreme storm surge levels along Europe. Climate Dynamics 47: 3171-3190.

Vousdoukas, M., Mentaschi, L., Voukouvalas, E., Verlaan, M., and Feyen, L. 2017. Extreme sea levels on the rise along Europe's coasts. Earth's Future 5(3): 304-323.

Wadey, M. P., Haigh, I. D., Nicholls, R. J., et al. 2015. A comparison of the 31 January-1 February 1953 and 5-6 December 2013 coastal flood events around the UK. Frontiers in Marine Science 2: 84. doi: 10.3389/fmars.2015.00084

Weatherhead, E. K., Knox, J. W., Daccache, A., et al. 2014. Water for Agriculture: Collaborative Approaches and On-farm Storage. FG1112 Final Report to Defra, Cranfield University.

Werner, A. D., Bakker, M., Post, V. E. A., et al. 2013. Seawater intrusion processes, investigation and management: Recent advances and future challenges. Advances in Water Resources 51: 3-26. https://doi.org/10.1016/j.advwatres.2012.03.004

Woth, K., Weisse, R., and Van Storch, H. 2006. Climate change and North Sea storm surge extremes: An ensemble study of storm surge extremes expected in a changed climate projected by four different Regional Climate Models. Ocean Dynamics 56: 3-15. 10.1007/s10236-005-0024-3. 